\title{
Brazil as an emerging economy: a new economic miracle?
}

EDMUND AMANN WERNER BAER*

This article shows that abundant resources and blind faith in an optimistic future cannot result in sustainable growth in Brazil. There are great deficiencies in various areas which make sustained high growth rates almost impossible to achieve, such as the low investment ratio, deficiencies in creating human capital, high interest rates leading to an uncompetitive exchange rate and a lack of infrastructural development.

Keywords: growth; infrastructure; investment; exchange rate; equity.

jel classification: 011;012;043; 054 .

\section{INTRODUCTION}

The Brazilian economy has become one of the great emerging markets.

Success stories in recent years, attracting record inward investment and international financial press plaudits in equal measure ${ }^{1}$. We aim to look behind the headlines at the reality, critically evaluating the performance of the Brazilian economy in the first decade of the $21^{\text {st }}$ century.

On the face of things, a real transformation in the performance of Brazil's economy seems to have taken place. Instead of the financial instability, which characterised its economy for many decades, Brazil is receiving praise for its relative price stability, fiscal responsibility and rapid growth. The country has

\footnotetext{
* University of Manchester, e-mail: Edmund.amann@manchester.ac.uk; Professor of economics at University of Illinois at Urbana-Champaign, e-mail wbaer@illinois.edu. Submitted: 4/April/2011; Approved 25/July/2011.

${ }^{1}$ See, for example, The Economist, February $19^{\text {th }} 2011$, "The buys from Brazil".
} 
become a highly favoured destination for capital flows, attracting $4.3 \%$ of the global total for 2010 (UNCTAD, 2011). Indeed, seeking to prevent exchange rate overshooting, the authorities have been forced to impose a tax on capital movements.

Brazil has become renowned for its export prowess in such fields as soya, steel, cotton, oil, biofuels and regional aircraft. As if this were not enough, the resurgence of the Brazilian economy has been associated with declines in income inequality and the incidence of extreme poverty. In other words, Brazil is touted as an example of the compatibility of growth and equity. Thus, it would seem that the old joke of referring to Brazil as "the country of the future that would always remain that way" is no longer true 2 . The approach of the 2014 World Cup and the 2016 Olympic Games, both to be held in Brazil, seem to indicate that the country has finally "arrived".

The aim of this article is to determine whether the current optimism surrounding the Brazilian economy is justified when its attributes are more closely examined. Many have claimed that the current favourable growth conditions of Brazil had their origins in the macroeconomic and market reforms of the mid 1990s. These reforms comprised a successful stabilisation plan (the Real Plan), banking reform, privatization and a substantial greater openness of the economy to foreign trade and investment (Blanco, Holanda Barbosa Filho \& Pessoa 2011, pp. 101-103; Baer, 2008, chs. $7 \& 8$ ). Our analysis will therefore concentrate on the period extending from the mid-1990s when most of the reforms took place to the present (2011).

\section{GROWTH}

An examination of Table 1 should make it obvious that Brazil's growth was relatively modest. The average annual growth rate in the period 1995-2003 was $2.2 \%$, which is quite weak by international standards. Substantial growth took place from $2004-2008$ when the annual growth rate was $4.8 \%$. There was a slump in 2009 as a result of the world crisis when growth was $-0.6 \%$. However, in 2010 growth jumped to $7.5 \%$. Compared to the growth experiences of many Asian countries this is not a spectacular achievement. However, the acceleration in growth has helped unemployment rates to decline. At the end of 2010, formal unemployment in Brazil hit an historic low of $5.7 \%$ according to data released by, IBGE, the national statistical agency.

\footnotetext{
${ }^{2}$ During WWII the famous Austrian writer Stefan Zweig who lived in exile in Brazil wrote a book on the country entitled "Brazil: Land of the Future" (Brazil, Land of the Future (Original title: Brasilien. Ein Land der Zukunft; Bermann-Fischer, Stockholm, 1941)) in which he described the country's potential. Many subsequent wits have added the rejoinder that it always would be.
} 
Table 1: Brazil Yearly Growth Rate of some components of GDP

\begin{tabular}{|l|c|c|c|c|}
\hline & $1995-2003$ & $2004-2008$ & 2009 & 2010 \\
\hline GDP & $2.2 \%$ & $4.8 \%$ & $-0.6 \%$ & $7.5 \%$ \\
\hline Agriculture & & & & \\
\hline & $4.5 \%$ & $3.59 \%$ & $-4.56 \%$ & $6.46 \%$ \\
\hline Industry & & & & \\
\hline Mining & $1.45 \%$ & $4.27 \%$ & $-6.42 \%$ & $10.12 \%$ \\
\hline Manufacture & $2.99 \%$ & 4.97 & $-1.06 \%$ & $15.68 \%$ \\
\hline Construction & $1.27 \%$ & $4.15 \%$ & $-8.23 \%$ & $9.69 \%$ \\
\hline & $0.62 \%$ & $2.91 \%$ & $-6.28 \%$ & $11.63 \%$ \\
\hline Capital Gds. & & & & \\
\hline Durable Consumer Gds & 0,36 & 3.14 & -17.43 & $21.8 \%$ \\
\hline Non-Durable Consumer Gds & 3.14 & 10.38 & -6.38 & $10.2 \%$ \\
\hline & 0.82 & 3.19 & -1.54 & $5.1 \%$ \\
\hline Services & & & & \\
\hline Commerce & $2.19 \%$ & $4.78 \%$ & $2.19 \%$ & $5.42 \%$ \\
\hline Finance & $1.75 \%$ & $6.30 \%$ & $-1.93 \%$ & $10.74 \%$ \\
\hline Government & $-2.70 \%$ & $9.08 \%$ & $7.09 \%$ & $10.68 \%$ \\
\hline Informatics & $2.77 \%$ & $2.40 \%$ & $3.32 \%$ & $2.30 \%$ \\
\hline & $9.81 \%$ & $5.49 \%$ & $4.88 \%$ & \\
\hline Fixed Capital Formation & $0.51 \%$ & $9.95 \%$ & $-10.3 \%$ & $21.85 \%$ \\
\hline
\end{tabular}

Source: Banco Central do Brasil

Table 2: Macro Ratios* and composition of GDP

\begin{tabular}{|l|c|c|c|c|c|}
\hline & $1995-2003$ & $2004-2008$ & 2009 & 2010 & \\
\hline Fixed Capital Formation / GDP* & 16.74 & 16.92 & 16.95 & 18.45 & \\
\hline Private Consumption / GDP & 63.61 & 60.11 & 62.76 & & \\
\hline Government Cons. / GDP & 20.10 & 19.80 & 20.81 & & \\
\hline Capacity Utilization & 81.7 & 84.3 & 80.2 & 86.1 & \\
\hline & & & & & \\
\hline & 1995 & 2000 & 2005 & 2009 & 2010 \\
\hline Agriculture/GDP & 5.77 & 5.60 & 5.71 & 6.08 & 6.77 \\
\hline Mining/GDP & 0.82 & 1.59 & 2.46 & 1.28 & 2.51 \\
\hline Manufacturing & 18.62 & 17.22 & 18.09 & 15.81 & 15.75 \\
\hline Construction & 5.49 & 5.52 & 4.90 & 4.93 & 5.27 \\
\hline Commerce & 11.71 & 10.60 & 11.17 & 11.79 & 11.86 \\
\hline Informatics & 0.70 & 3.60 & 3.98 & 3.64 & \\
\hline Finance & 9.03 & 5.96 & 7.05 & 7.30 & 7.68 \\
\hline Public Adm. & 15.59 & 14.93 & 15.05 & 17.02 & 16.51 \\
\hline
\end{tabular}

*Yearly averages

Source: Banco Central do Brasil; IPEA 
Another remarkable phenomenon is the persistence in Brazil of a low investment-GDP ratio. As Table 2 shows, this has hovered at just under $17 \%$, barely shifting despite the acceleration of growth in certain years. This is striking when one takes into account that many Asian countries, whose growth rates have been higher than Brazil, enjoyed investment-GDP ratios of around 35-40\%. This would mean either that Brazil's investments are dramatically more efficient than those of Asia or that growth under current circumstances cannot be expected to continue. By the best estimates available, with the current investment-GDP ratio, Brazil's long term annual average potential growth rate for GDP is no more than $4.5 \%^{3}$. In this sense the recent spurt in growth $(7.5 \%$ p.a. in 2010) is clearly unsustainable without a dramatic rise in investment.

\section{INFRASTRUCTURE}

An important feature of investment in an emerging country like Brazil concerns the expansion and improvement of infrastructure. In the period covered by this article there has been a neglect of investment in this area. Since the 1990s there has been a notorious lag in building and improving the country's transportation network and shipment facilities. Thus, for example, at harvest time queues of trucks extending to 20-25 miles wait to discharge their loads at overstretched ports ( $O$ Globo, 11/2/2011). Some major industrial areas have been threatened by blackouts due to a substantial lag in the construction of electricity generation and transmission facilities. A particularly high profile shortcoming lies in the airport sector. Here, much needed investments in runway and terminal construction have been held back. This represents a real challenge given booming domestic demand for air travel.

What might account for these high profile infrastructural shortcomings? One of the key factors at work here is the pursuit of attaining high primary surplus budget targets in order to satisfy the international financial community and to hold inflation in check $^{4}$. It is true that in 2007 the government instituted a programme called PAC (Growth Acceleration Programme). This programme was meant to effect a steep change in GDP growth after the disappointing growth performance realised in the 1996-2004 period. Many of the PAC projects are infrastructural in nature but for various reasons they have met with delay or cancellation due to both budgetary and administrative shortcomings. The problems here are made even more urgent by the approach of the 2014 World Cup and the 2016 Olympic Games. These two international events will place particular pressure on the country's faltering infrastructure, not least in the area of transportation.

\footnotetext{
${ }^{3}$ For the influence of Total Factor Productivity on growth in the period 1994-2010 see Blanco, Holanda Barbosa Filho and Pessoa in Nabli (2011).

${ }^{4}$ For more discussion see Amann \& Baer (2006).
} 
The spectacular success of the Real stabilisation plan (introduced in 1993-4) was in part connected with the appreciation of Brazil's currency, which was due to high interest rates that were important stabilisation instruments that were used at the time (Baer, 2008, ch. 7). These high base interest rates (varying between $7 \%$ and $10 \%$ in real terms) attracted a substantial amount of capital which appreciated the currency and thus facilitated the stabilisation efforts. For a while this came to be known as a policy of controlling inflation via an exchange rate anchor (Amann \& Baer, 2003). Although this policy was discontinued at the turn of the century and a policy of "inflation targeting" was introduced there was a continued emphasis on the use of high interest rates to underpin price stability. Since that time Brazil's interest rates have been among the highest in the world and have attracted substantial portfolio inflows (some speculative in nature) (see Table $3 \mathrm{~b}$ ) which in turn have led Brazil to have one of the most appreciated currencies in the emerging world.

Table 3:

a) Brazil's export and import growth rates

\begin{tabular}{|l|c|c|c|c|}
\hline & $1995-2003$ & $2004-2008$ & 2009 & 2010 \\
\hline Exports & $6.66 \%$ & $7.04 \%$ & -10.28 & 9.0 \\
\hline Imports & $8.09 \%$ & $15.61 \%$ & -11.41 & 18.1 \\
\hline
\end{tabular}

Source: Banco Central do Brasil

b) Brazil's trade balance, net foreign direct investment and portfolio investment (US $\$$ bn.)

\begin{tabular}{|c|c|c|c|}
\hline & Trade balance & Net FDI & Net Portfolio Investment \\
\hline 1996 & -5.6 & 11.3 & 21.6 \\
\hline 1997 & -6.8 & 17.9 & 12.6 \\
\hline 1998 & -6.6 & 26.0 & 18.1 \\
\hline 1999 & -1.2 & 26.9 & 3.8 \\
\hline 2000 & -0.7 & 30.5 & 7.0 \\
\hline 2001 & 2.7 & 24.7 & 0.07 \\
\hline 2002 & 13.1 & 14.1 & -5.1 \\
\hline 2003 & 24.8 & 9.8 & 5.3 \\
\hline 2004 & 33.6 & 8.3 & -4.7 \\
\hline 2005 & 44.7 & 12.5 & 4.9 \\
\hline 2006 & 46.5 & -9.4 & 9.1 \\
\hline 2007 & 40.0 & 27.5 & 48.4 \\
\hline 2008 & 24.8 & 24.6 & 1.1 \\
\hline 2009 & 25.3 & 36.0 & 50.3 \\
\hline 2010 & 20.3 & 37.0 & 64.5 \\
\hline
\end{tabular}


The strong Real has made it very difficult for the country's industries to achieve international competitiveness. However, this has not resulted in balance of payments difficulties since, at the same time, there developed over the decade a world commodity boom which originated in the high growth rates of a number of Asian countries led by China. In fact, there were a number of years when Brazil achieved trade surpluses (see Table 3b). Over the second half of the 2000s, commodities amounted to more than $50 \%$ of exports. Moreover, the proportion of exports accounted for by commodities exports has been increasing (IPEA, 2010). This is ironic since what originally led Brazil and similar countries to industrialise was too great a dependence on the export of commodities.

However, Brazil's lack of competitiveness in the export of manufactures is not necessarily due to inefficiencies but rather due to the anomaly of an appreciated exchange rate resulting from the dictates of inflation targeting. This problem has become especially acute in relation to the increasing competitive challenge posed by Chinese manufacturing in both domestic and foreign markets according to a 2011 survey conducted by the Brazilian National Industrial Confederation (CNI, 2011; see also Da Costa, 2010). In an attempt to support the expansion of exports against the backdrop of an appreciated exchange rate the authorities announced a package of incentives in late 2010. These include tax exemptions on domestically sourced inputs into exported products (O Globo, $21^{\text {st }}$ December 2010).

\section{THE BOOM IN CREDIT}

A notable feature of Brazil's economy in the period under review is the growth of the use of credit, especially consumer credit. It will be noted in Table 4 that the ratio of bank credit to GDP has risen from $26.7 \%$ in 1998 to $28.1 \%$ in 2005 and $47 \%$ in 2010 . This trend complemented the above mentioned government effort to stimulate the economy through tax incentives. For instance, the Financial Times found that "the situation in Brazil is worryingly similar to the sub-prime crisis in the U.S. A lot of credit is being pushed by the banks at high rates to consumers who ultimately won't be able to service the debt" 5 . According to a research organization, Serasa, consumer credit defaults rose $6.3 \%$ in 2010 , a considerable rise on previous years. One result of the boom in consumer credit has been an acceleration in the sale of automobiles. In 2010 sales of vehicles hit a historical high of 3.5 million units, a jump of $11 \%$ on the previous year.

\footnotetext{
${ }^{5}$ Financial Times, February $21^{\text {st }} 2011$.
} 
Table 4: Brazil: Bank Credit as \% of GDP

\begin{tabular}{|c|c|}
\hline 1998 & 24.7 \\
\hline 2005 & 28.1 \\
\hline 2005 & 30.8 \\
\hline 2007 & 34.7 \\
\hline 2008 & 41.3 \\
\hline 2009 & 45.9 \\
\hline $2010^{*}$ & 50.0 \\
\hline
\end{tabular}

* preliminary estimate.

Source: Banco Central do Brasil

\section{GROWTH AND EQUITY}

A constant in Brazil's economic history has been a high concentration in the distribution of income. This was at first the result of the concentration of land ownership in a primary product export oriented economy of the $19^{\text {th }}$ and the first half of the $20^{\text {th }}$ centuries. This concentration continued under the ISI model as the industrial sectors which were implanted had high capital intensity. It also worsened in the very high inflationary years in which low income groups suffered the most. From the introduction of the Real Plan to the end of the first decade of the $20^{\text {th }}$ Century these historical trends seem to have been reversed (Amann \& Baer, 2009). This was shown by the decline of the Gini coefficient by around $4.5 \%$ between 2005 and 2009 (De Mello, 2011).

The decline in inequality has been accompanied by the increasing economic salience of "The C Class" or "new middle class" (Neri, 2009). According to Neri (2010) "some $29 \mathrm{~m}$ people entered this class from the lower D and E classes between 2003 and 2009. The C class - the third quintile of the income distribution - rose proportionately more than the other classes. By 2009 it contained $94 \mathrm{~m}$ people, representing more than half of the population (ibid.)".

There seems to be a substantial debate about the circumstances which have led to the decline in inequality. Some have claimed that this was due to the introduction of a cash transfer programme in the administration of Fernando Henrique Cardoso which was consolidated by the Lula administration in what came to be known as the Bolsa Família. There is no doubt that the Bolsa Família has eliminated extreme poverty in the lowest income groups. However, as the sum spent on it amounted to at best $1 \%$ of GDP it is questionable whether this programme has had a substantial underlying distributional impact.

This is especially interesting when we contrast it with the amount the government spends on servicing debt, which amounts to at least $7 \%$ of GDP. The owners of this debt, do not, as a rule belong to the lower income groups. Other analysts attribute the improvement in the distribution of income more to the elimination of inflation and the substantial rise in the real minimum wage which has influenced not only the income of the poorest groups, but others besides. As Table $5 \mathrm{~b}$ indicates, the minimum wage has risen substantially since the late 1990s. However, only those 
in receipt of social security payments or in formal employment have been in a position to benefit here. According to a report released by IPEA $16 \%$ of a sample of workers interviewed did not receive the minimum wage (O Globo, 16/2/2011).

Table 5:

a) Brazil: Changes in Real Earnings.

\begin{tabular}{|l|c|c|c|c|}
\hline & $1995-2003$ & $2004-2008$ & 2009 & 2010 \\
\hline $\begin{array}{l}\text { Average Real Earnings } \\
\text { of Employed individuals }\end{array}$ & $\begin{array}{c}\mathrm{R} \$ 1,316 \\
(2002-2003)\end{array}$ & $\mathrm{R} \$ 1,292$ & $\mathrm{R} \$ 1,409$ & $\mathrm{R} \$ 1,543$ \\
\hline Real Salary (Jan. 06) =100 & 90.52 & 96.59 & 111.53 & 114.02 \\
\hline $\begin{array}{l}\text { Real Average } \\
\text { Salary (Jan. '06 = 100) }\end{array}$ & 87.11 & 97.00 & 102.66 & 103.30 \\
\hline
\end{tabular}

Source: IPEA Data; Conjuntura Econômica

b) Brazil: Changes in the Minimum Wage (in $\mathrm{R} \$$ )

\begin{tabular}{|c|c|c|}
\hline 1995 & 90.00 & Rate of Growth \\
\hline 1996 & 108.00 & $20.0 \%$ \\
\hline 1997 & 117,33 & $8.6 \%$ \\
\hline 1998 & 126,67 & $8.0 \%$ \\
\hline 1999 & 134,00 & $5.8 \%$ \\
\hline 2000 & 147,25 & $9.9 \%$ \\
\hline 2001 & 172,75 & $17.3 \%$ \\
\hline 2002 & 195,00 & $12.9 \%$ \\
\hline 2003 & 230,00 & $24.3 \%$ \\
\hline 2004 & 253,33 & $10.01 \%$ \\
\hline 2005 & 286,67 & $13.2 \%$ \\
\hline 2006 & 337,50 & $17.7 \%$ \\
\hline 2007 & 372,50 & $10.4 \%$ \\
\hline 2008 & 415,00 & $11.4 \%$ \\
\hline 2009 & 465,00 & $12.0 \%$ \\
\hline 2010 & 510,00 & $9.7 \%$ \\
\hline
\end{tabular}

Source: IPEA Data

Substantial emphasis has been placed on the fact that Brazil's tax burden has increased substantially in the period examined, reaching a level of $37 \%$ of GDP. This level, which is similar to that of such countries as Sweden and Germany has existed in combination with a continued high concentration of income. What explains this puzzle? Brazil's tax structure is still quite regressive. However, what is even more regressive is the structure of government expenditures. This is an aspect contributing to the continued high concentration in the distribution of income which has yet to be addressed (Baer \& Galvão, 2008). Another point to bear in mind is that the Gini measures the distribution of earned income (wages and salaries). It does not measure the distribution of wealth. As the privatization programme of Brazil consisted mainly of the sale of government assets through auc- 
tions, much of the wealth of state companies was bought up by large Brazilian and foreign groups and thus indications exist that skewness in the distribution of wealth has actually increased (Amann \& Baer, 2009). This leads us to the question of whether further substantial improvements in the distribution of income can be realised in the context of a highly skewed pattern of asset ownership.

\section{MARKET VERSUS STATE-ORIENTED DEVELOPMENT}

The advocates of privatization and other neo-liberal reform measures have argued that the market is the best instrument to select winners in the process of economic development. Although this view is widely held, it is called into question by the experience of many of the East Asian newly industrialised economies. Here, governments have repeatedly engaged, with some success, in "picking winners" (Stiglitz \& Cimoli, 2009). It would seem to us that in spite of the widespread privatization which has taken place in Brazil the state is still playing a substantive role through a state-owned development banking institution known as the BNDES.

Despite the substantial modernization of Brazil's capital market over the past decade it is rare for any major Brazilian firm to finance long-term expansion by borrowing from private markets. Most firms, especially large firms, depend on long-term loans from the BNDES. In 2010 BNDES disbursement to large firms accounted for almost three quarters of the total. Sectorally, $47 \%$ went to industrial firms and $31 \%$ to firms engaged in infrastructure (BNDES, Boletim de Desempenho, December 2010). The BNDES has received a huge increase in its capital from the Lula administration. Immediately prior to the October 2010 presidential election, the government announced a further $\mathrm{R} \$ 30$ billion injection of funds into the BNDES (O Globo, 27/9/2010). One consequence of the increase in public funding for the BNDES has been an increase in overall public debt as the government capitalises the Bank through bond issuance (O Globo, 1/2/2011). Over the past five years or so, the proportion of overall fixed investment financed by the BNDES has actually risen although, as we have seen, the investment to GDP ratio has remained at a relatively low level (Hermann, 2010). Hence, it can be said that in regard to investment, the role of the state is becoming more rather than less significant.

\section{CONTINUED INSTITUTIONAL WEAKNESSES}

In addition to the above mentioned required improvements in the country's physical infrastructure, sustained growth needs a continued rising stock of human capital. Unfortunately, in the case of Brazil, the existence, growth and improvement of human capital needs to be substantially strengthened in order to achieve high rates of growth.

Perhaps the most fundamental problem centres on the education system. Here, 
according to many measures - illiteracy, school attendance, investment, school performance, and graduation - Brazil lags behind its East Asian newly industrialised emerging economy counterparts. According to a 2010 report by UNESCO, Brazil has the highest rate of primary school students repeating years in Latin America $(18.7 \%)$ and has one of the highest dropout rates in the region. Barro \& Lee (2010), in constructing an international comparative index of educational attainment, also illustrate the scale of the challenges that Brazil faces. As Table 6 indicates, according to their index, Brazil lags behind other major economies in the region and its performance is even less favourable when compared with countries in Europe and Asia. There are clear implications here in terms of the degree to which Brazil might be able to close the productivity gap which has opened up between itself and its key trading partners.

Table 6: Average educational attainments of the adult population, selected countries 1960-2010

\begin{tabular}{|l|c|c|c|c|c|}
\hline & 1960 & 1990 & 2000 & 2010 & Ratio 2010/1990 \\
\hline Argentina & 5.3 & 7.9 & 8.6 & 9.3 & 1.2 \\
\hline Brazil & 1.8 & 3.8 & 5.6 & 7.2 & 1.9 \\
\hline Chile & 5.0 & 8.1 & 8.8 & 9.7 & 1.2 \\
\hline Colombia & 2.8 & 5.5 & 6.5 & 7.3 & 1.3 \\
\hline Mexico & 2.6 & 5.5 & 7.4 & 8.5 & 1.5 \\
\hline Peru & 3.2 & 6.6 & 7.7 & 8.7 & 1.3 \\
\hline Canada & 8.1 & 10.3 & 11.1 & 11.5 & 1.1 \\
\hline France & 4.1 & 7.1 & 9.3 & 10.4 & 1.5 \\
\hline UK & 6.0 & 7.9 & 8.5 & 9.3 & 1.2 \\
\hline USA & 8.9 & 12.3 & 13.0 & 12.4 & 1.0 \\
\hline China & 1.4 & 4.9 & 6.6 & 7.5 & 1.6 \\
\hline Japan & 7.2 & 9.9 & 10.7 & 11.5 & 1.2 \\
\hline South Korea & 3.2 & 8.9 & 10.6 & 11.6 & 1.3 \\
\hline OECD average & 6.1 & 8.9 & 9.9 & 10.7 & 1.2 \\
\hline
\end{tabular}

Source: Barro \& Lee (2010)

Over the past decade, there is evidence to suggest that, as a group, Brazilian enterprises are becoming more innovative (IPEA, 2010b). As Table 7b indicates, the proportion of firms engaging in innovative activities has risen since the late 1990s by approximately five percentage points. However, as Table 7a shows, in international comparative terms only modest resources are devoted to research and development. In particular, compared to older industrial countries, resources targeted at $\mathrm{R} \& \mathrm{D}$ are small. One result is the small contribution of Brazil to the world's technical knowledge. For instance, as can be seen in Table $7 \mathrm{c}$, the number of patents granted to Brazilian residents is extremely small when compared with other industrialised economies. 
Table 7:

a) Research and Development of Firms as \% of GDP

\begin{tabular}{|l|c|c|}
\hline & 2005 & 2008 \\
\hline Portugal & 0.31 & 0.76 \\
\hline Spain & 0.60 & 0.74 \\
\hline China & 0.90 & 1.08 \\
\hline Denmark & 1.68 & 1.91 \\
\hline Finland & 2.46 & 2.77 \\
\hline USA & 1.79 & 2.00 \\
\hline Brazil & 0.49 & 0.54 \\
\hline Italy & 0.55 & 0.60 \\
\hline Germany & 1.72 & 1.84 \\
\hline France & 1.30 & 1.27 \\
\hline Holland & 1.01 & 0.89 \\
\hline
\end{tabular}

Source: OECD, Community Innovation Survey, via IPEA, Radar No. 11, December 2010.

b) Brazil: Percentage of firms that engage in innovative activities

\begin{tabular}{|c|c|c|c|}
\hline Years & $\begin{array}{c}\text { Innovative } \\
\text { Activities }\end{array}$ & Internal R\&D & $\begin{array}{c}\text { External; Acquisition } \\
\text { of Innovation }\end{array}$ \\
\hline $1998-2000$ & 26.62 & 10.29 & 2.32 \\
\hline $2001-2003$ & 24.45 & 5.86 & 1.43 \\
\hline $2003-2005$ & 21.91 & 5.54 & 1.35 \\
\hline $2006-2008$ & 30.49 & 4.25 & 1.41 \\
\hline
\end{tabular}

Source: IBGE

c) Patenting activity: international comparisons 2008 (registered US patents)

\begin{tabular}{|l|c|}
\hline USA & 257818 \\
\hline Japan & 84473 \\
\hline Germany & 26331 \\
\hline South Korea & 25507 \\
\hline Canada & 11436 \\
\hline UK & 10795 \\
\hline France & 9281 \\
\hline China & 5148 \\
\hline Israel & 4916 \\
\hline Italy & 4273 \\
\hline Australia & 4194 \\
\hline Singapore & 1376 \\
\hline Spain & 1294 \\
\hline Russia & 531 \\
\hline Brazil & 499 \\
\hline Mexico & 269 \\
\hline Argentina & 139 \\
\hline Chile & 63 \\
\hline
\end{tabular}




\section{CONCLUSIONS}

Our discussion is not meant to minimise the achievements of Brazil in the many spheres of its economic activities. However, we felt it should be made clear that abundant resources and blind faith in an optimistic future cannot result in sustainable growth. We have shown that there are great deficiencies in various areas which will make sustained high growth rates almost impossible to achieve. There needs to be a carefully balanced growth programme which takes into account the long- term needs of Brazilian society. These needs are especially acute in regard to adequate infrastructure, sustained high levels of investment, development of adequate human capital.

\section{BIBLIOGRAPHY}

AMANN, E. and BAER, W. (2003) 'Anchors away: the costs and benefits of Brazil's devaluation', World Development, Vol. 31 no. 6, pp. 1033-1046.

AMANN, E. and BAER, W. (2006) 'Economic orthodoxy versus social development? The dilemmas facing Brazil's labour government' (with W. Baer), Oxford Development Studies, Vol. 34, no.2, pp. 219-241.

AMANN, E. and BAER, W. (2009) 'The macroeconomic record of the Lula administration, the roots of Brazil's inequality and Brazil's attempts to overcome them', in J. Love (ed.) The Political Economy of Brazil's Lula Administration, Palgrave, New York.

BAER, W. (2008) The Brazilian Economy: Growth and Development, $6^{\text {th }}$ Edition, Boulder, Lynne Rienner.

BAER, W. and GALVÃO, A. F. (2008) 'Tax burden, government expenditures and income distribution in Brazil, Quarterly Review of Economics and Finance, 2, pp. 345-359.

BARRO, R.J. and J.W. LEE (2010) 'A new data set of educational attainment in the world, 1950-2010,' NBER Working Paper, 15902.

BLANCO, F., F. HOLANDA Barbosa Filho and S. PESSOA (2011) 'Brazil: resilience in the face of the global crisis', in Nabli, M. K. (ed.) (2011) The Great Recession and Developing Countries, Washington, The World Bank.

CIMOLI, M. DOSI, G. and STIGLITZ, J. (2009) Industrial Policy and Development, Oxford, Oxford University Press.

CNI (2011) Sondagem Especial: China, Rio de Janeiro, Confederação Nacional de Indústria.

DA COSTA, Achyles Barcelos (2010). 'The footwear industry in Vale dos Sinos (Brazil): competitive adjustment in a labour-intensive sector.' CEPAL Review 101, pp. 157-172.

HERMANN, J. (2010) 'Development banks in the financial liberalisation era: the case of BNDES in Brazil', CEPAL Review, 100, pp. 189-205.

IPEA (2010) O Brasil em 4 Décadas, Texto para Discussão 1500, Rio de Janeiro, IPEA.

IPEA (2010b) Radar - Tecnologia, Produção e Comércio Exterior, no. 11, Rio de Janeiro, IPEA.

DE MELLO, L. (2011) 'Brazil's achievements and challenges', CESifo Forum, (1), pp. 3-16.

NERI, M. (2009) 'Brazil as an equitable opportunity society' in L. Brainard and L. Martinez-Diaz (eds.) Brazil as an Economic Superpower, Washington DC, Brookings Institution.

NERI, M. (2010) The New Middle Class in Brazil: The Bright Side of the Poor, Rio de Janeiro, FGV. UNCTAD (2011) World Investment Report 2010, Geneva, UNCTAD. 